\title{
'Fuentepina' Strawberry
}

Carmen Soria ${ }^{1}$, Juan J. Medina, Pedro Domínguez, María T. Ariza, Luis Miranda, Rosalía Villalba, Josefa Gálvez, José F. Sánchez-Sevilla, Iraida Amaya, Rafael Sesmero, and José M. López-Aranda

Instituto Andaluz de Investigación y Formación Agraria y Pesquera (IFAPA), Consejería de Agricultura y Pesca, Junta de Andaluciá, Avda. Isaac Newton $n^{\circ}$ 3, $2^{a}$ planta, Parque Tecnológico Cartuja '93, 41092 - Seville, Spain

Additional index words. Fragaria $\times$ ananassa, fruit breeding, cultivar

Over recent years, there has been a significant shift in the range of strawberry (Fragaria xananassa Duch.) cultivars used by growers in Huelva (a major strawberry-producing area in southwestern Spain). Until only 2 or 3 years ago, a single cultivar of largely Californian origin predominated; currently, two, three, or even more cultivars coexist. Access to a wide range of cultivars gives growers the opportunity to choose according to their needs; earliness and higher organoleptic quality are currently among the most desirable properties for growers and consumers alike.

To meet the new demand, the Spanish National Strawberry Breeding Program - an initiative involving several public institutions, including the Instituto Nacional de Investigaciones Agrarias (INIA), the Instituto de Investigación y Formación Agraria y Pesquera (IFAPA) de la Junta de Andalucía, and the Instituto Valenciano de Investigaciones Agrarias (IVIA) as well as the private partners Fresas Nuevos Materiales S.A. (FNM), Nuevas Técnicas en Fresa S.A. (NTF), and Freshuelva viveristas $(\mathrm{FV})$ - is working to obtain new and improved cultivars (López-Aranda et al., 2004, 2005a, 2005b; Soria et al., 2008). The most recent result of this breeding program is the cultivar Fuentepina.

'Fuentepina' is an early midseason, shortday cultivar adapted to the protected growing conditions of Huelva (Spain). Its most outstanding feature is its excellent flavor as a result of a very high sugar/acid ratio. 'Fuentepina' has good fresh-market qualities.

The name 'Fuentepina' (more properly, Fuentepiña) is that of a well-known strawberryproducing area in Huelva, made famous by the works of the Spanish writer Juan Ramón Jiménez, winner of the 1956 Nobel Prize for Literature.

\section{Origin}

'Fuentepina' was selected from a 2002 cross between NA-676 (IFAPA Genebank

Received for publication 12 Nov. 2009. Accepted for publication 4 Jan. 2010.

We thank INIA Project RTA2007-00012, INIA Agreement CC05-024-C3-1, and FEDER funds (European Union) for financial support.

We thank Mr. Paul Edson for the English revision. ${ }^{1}$ To whom reprint requests should be addressed; e-mail maria.soria@juntadeandalucia.es. accession) and the breeding line SE-1-297 ('Oso Grande' $\times$ 'Carisma') and was tested as selection 1823-1. The female parent NA-676 is a short-day accession with a high early and total production of large to very large firm fruit. SE-1-297 was chosen as the male parent for its good sensory properties in previous field tests. Both parents are also very well adapted to growing conditions in Huelva.

From 2003, 'Fuentepina' was propagated for performance evaluations at high-elevation nurseries in Castille-Leon, northeastern Spain (altitude 900 to $1200 \mathrm{~m}$ ). Its clones were later evaluated, together with other well-adapted cultivars, in replicated plot trials in a state-run experimental field in the strawberry-producing area of Moguer (Huelva).

\section{Description}

'Fuentepina', a short-day strawberry cultivar, is described following the International Union for the Protection of New Varieties of Plants (UPOV) guidelines (UPOV, 1995). Plants are vigorous with a globose growth habit. They tend to produce a moderate number of runners with low anthocyanin coloration and medium pubescence when planted in mid-April in high-elevation nurseries. The leaves are strongly concave and weakly blistering with three dark green medium-glossy leaflets. The terminal leaflet is longer than wide with an obtuse base and crenate margins. Inflorescences are produced on long peduncles and flowers open at the level of the canopy. Flower size is large and the calyx diameter is greater than the corolla. The corolla has five overlapping white petals, which are broader than long. The biconical to wedge-shaped berries (Fig. 1) are large and slightly lighter red on the outside than the other cultivars tested (Table 1); flesh is orange-red, and the internal cavity is either absent or very weakly expressed. The fruit surface is even, and achenes are inserted level with the surface. The calyx is firmly attached to the fruit and its diameter is slightly larger than that of the fruit. The fruit is pleasantly aromatic and tasty. Postharvest testing showed that 'Fuentepina' has a good shelf life, similar to that of 'Camarosa' and 'Sabrosa' and longer than of 'Aguedilla' and 'Ventana' (Table 2). Early and total yields for 'Fuentepina' are slightly lower than those of standard cultivars grown in southwestern Spain such as 'Camarosa' (Table 1). 'Fuentepina' is remarkable for its low tendency to form misshapen fruits and its low percentage of second-class fruits (no misshapen fruits of 10 to $17 \mathrm{~g}$; López-Aranda et al., 2005b).

Characterization of 'Fuentepina' (Gil-Ariza et al., 2006) using three microsatellites yielded the following patterns: ChFaM001: 244, 231, 212; ChFaM002: 164; and ChFaM004: 187, 173, 147, 145, 137.

\section{Performance}

During the crop seasons 2007-2008 (2008) and 2008-2009 (2009), fruit production and quality (Table 1) and shelf life parameters (Table 2) for 'Fuentepina' were compared with those of three other welladapted strawberry cultivars: Aguedilla,

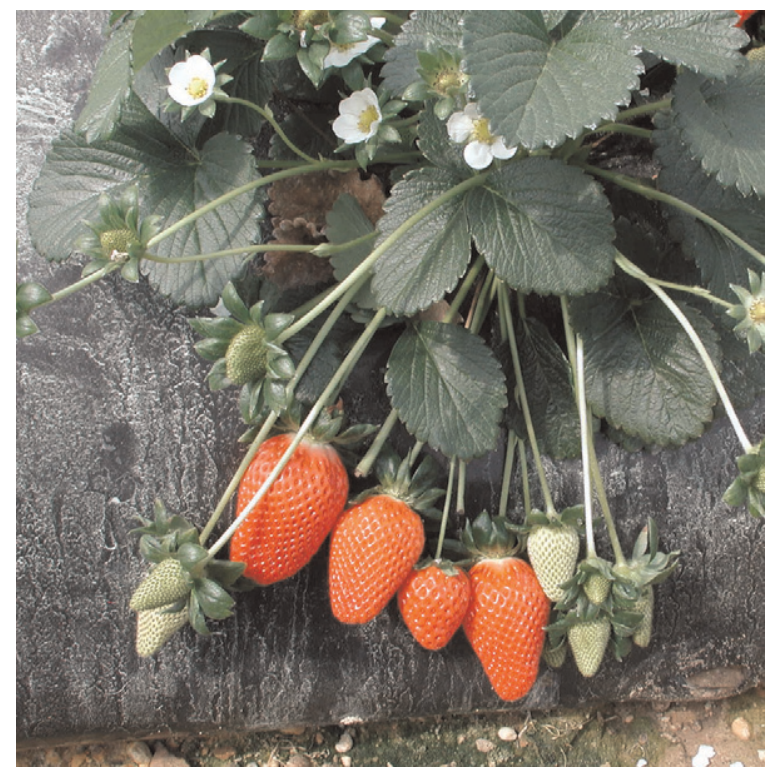

Fig. 1. Fruits of 'Fuentepina' strawberry. 
Table 1. Marketable yield and fruit quality of 'Fuentepina' and three other strawberry cultivars grown in Huelva, Spain, during the 2008 and 2009 crop seasons.

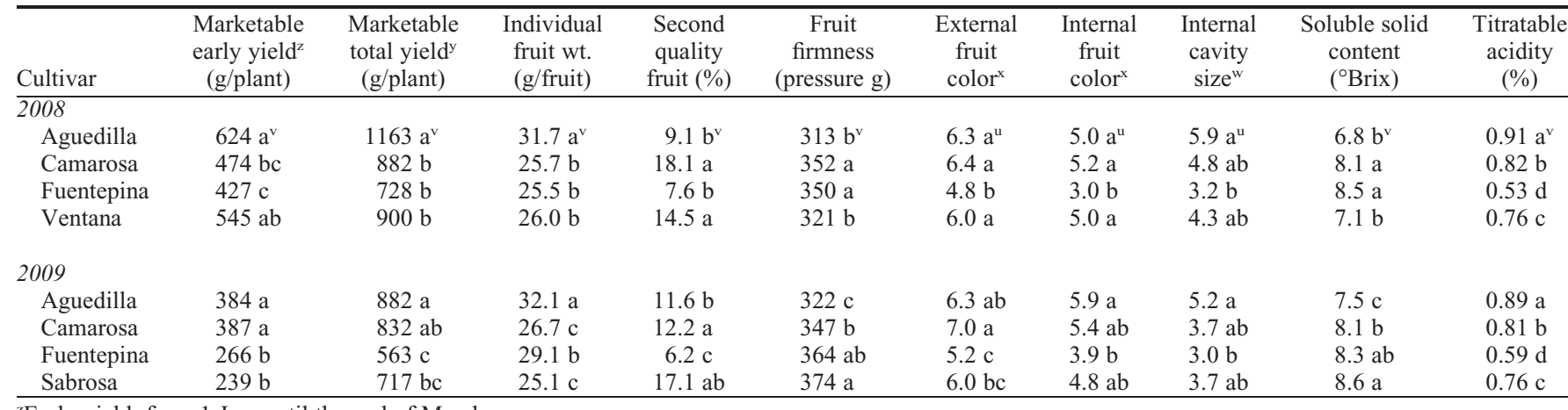

${ }^{2}$ Early yield: from 1 Jan. until the end of March.

${ }^{y}$ Total yield: from 1 Jan. until the end of May.

${ }^{\times}$Rated on a scale from 1 to 9 , in which $1=$ light red and $9=$ deep red.

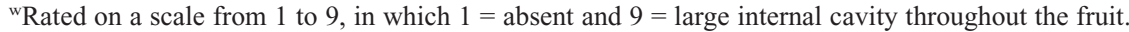

${ }^{\text {} W i t h i n ~ c o l u m n s, ~ m e a n s ~ f o l l o w e d ~ b y ~ d i f f e r e n t ~ l e t t e r s ~ a r e ~ s i g n i f i c a n t l y ~ d i f f e r e n t ~ a t ~} P \leq 0.05$ as determined by Fisher's least significant difference test.

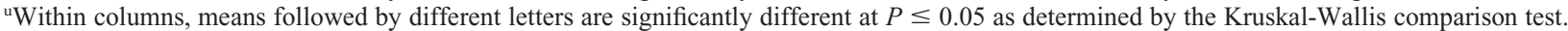

Table 2. Shelf life parameters of 'Fuentepina' and three other strawberry cultivars grown in Huelva, Spain, during the 2008 and 2009 crop seasons.

\begin{tabular}{lcc}
\hline Cultivar & Calyx freshness $^{\mathrm{z}}$ & Bruising $^{\mathrm{y}}$ \\
\hline 2008 & & \\
Aguedilla & $4.7 \mathrm{c}^{\mathrm{x}}$ & $4.3 \mathrm{~b}$ \\
Camarosa & $5.0 \mathrm{~b}$ & $6.3 \mathrm{a}$ \\
Fuentepina & $6.2 \mathrm{a}$ & $6.7 \mathrm{a}$ \\
Ventana & $3.7 \mathrm{~d}$ & $4.5 \mathrm{~b}$ \\
& & \\
2009 & $5.0 \mathrm{~b}$ & $3.7 \mathrm{c}$ \\
Aguedilla & $6.3 \mathrm{a}$ & $5.2 \mathrm{~b}$ \\
Camarosa & $6.1 \mathrm{a}$ & $5.6 \mathrm{ab}$ \\
Fuentepina & $5.0 \mathrm{~b}$ & $6.3 \mathrm{a}$ \\
Sabrosa-Candonga &
\end{tabular}

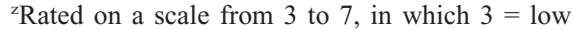
calyx freshness and $7=$ high calyx freshness.

${ }^{y}$ Rated on a scale from 3 to 7 , in which $3=$ highly bruised and $7=$ not bruised.

${ }^{\mathrm{x}}$ Within columns, means followed by different letters are significantly different at $P \leq 0.05$, as determined by the Kruskal-Wallis comparison test.

Camarosa, and Ventana in 2008 and Sabrosa instead of Ventana in 2009. In both years, performance was evaluated in experimental fields in the strawberry-producing of Moguer (Huelva, Spain). To reduce the presence of soil pathogens, the soil was solarized and biofumigated (Medina-Mínguez, 2002) before planting. During the last week of October of each year, plants were planted in three completely randomized plots of 75 plants each on two-row raised beds covered with black plastic and using drip irrigation pipes under the plastic. Plants were spaced $0.25 \times$ $0.25 \mathrm{~m}$ apart. In mid-November plants were covered with large plastic $(150 \mu)$ tunnels ( $6.6 \mathrm{~m}$ wide $\times 3.5 \mathrm{~m}$ high $\times 70 \mathrm{~m}$ long). Between mid-November and mid-May, the fertilizer rate used was: $175 \mathrm{~kg} \mathrm{~N} / \mathrm{ha}, 77 \mathrm{~kg}$ $\mathrm{P}_{2} \mathrm{O}_{5} / \mathrm{ha}, 185 \mathrm{~kg} \mathrm{~K}{ }_{2} \mathrm{O} / \mathrm{ha}$, $85 \mathrm{~kg} \mathrm{CaO} / \mathrm{ha}$, and $14 \mathrm{~kg} \mathrm{MgO} / \mathrm{ha}$. Marketable fruits (first plus second quality; no misshapen fruits of $17 \mathrm{~g}$ or greater or between 10 and $17 \mathrm{~g}$, respectively) were harvested and weighed once or twice a week from early January to late May. Individual fruit weight was calculated by dividing the total yield by the total number of harvested fruits. Six fruits per plot were evaluated three times throughout the cropping season (mid-February, mid-March, and mid-May) for external and internal color, internal cavity size, firmness, and soluble solid content and twice (mid-February and mid-May) for acidity. Color and cavity size were subjectively rated on a visual scale (Table 1). Fruit firmness was determined using a penetrometer with a $3.5-\mathrm{mm}$ tip, soluble solid content was measured using a refractometer (Dominguez et al., 2004), and acidity by an automatic titration unit. To estimate the shelf life of 'Fuentepina' in comparison with the other three cultivars, three times during the crop season, $500 \mathrm{~g}$ of mature fruits per plot were maintained in cold chamber $\left(4{ }^{\circ} \mathrm{C}\right)$ during $3 \mathrm{~d}$ and then $2 \mathrm{~d}$ at room temperature before evaluating calyx freshness and resistance to bruising. Data were subjected to analysis of variance using Statistix 8.0 software (Analytical Software, Tallahassee, FL) and means were separated at the 0.05 level using Fisher's least significant difference test or the Kruskal-Wallis comparison test (for subjective data). The percentage of second-quality fruit was arcsine transformed before statistical analysis.

Results for 'Fuentepina' yield, fruit quality, and shelf life parameters in replicated trials are provided in Tables 1 and 2. 'Fuentepina' recorded similar early and total yields to 'Camarosa' in 2008 and to 'Sabrosa' in 2009; values were lower than those of 'Aguedilla', which recorded the highest yields in both years. At the end of both trial harvest periods, 'Fuentepina' displayed the lowest percentage of second-quality fruit. The average fruit size was significantly smaller than for 'Aguedilla' but was similar to that recorded for 'Camarosa' and 'Ventana' in 2008 and higher than that of 'Camarosa' and 'Sabrosa' in 2009. Fully mature 'Fuentepina' fruits were lighter red, both on the outside and the inside, than the other cultivars. The internal cavity was either absent or very weakly expressed. 'Fuentepina' fruit firmness ranged from 350 to $364 \mathrm{~g}$ pressure, values similar to those displayed by 'Camarosa' in both 2008 and 2009 and higher than those recorded for 'Aguedilla'. Soluble solid content for 'Fuentepina' ranged from 8.3 to $8.5^{\circ} \mathrm{Brix}$; these values were similar to those of 'Camarosa' and 'Sabrosa' and significantly higher than those of 'Aguedilla'. The sugar/acid ratio was higher than for the other cultivars. During both crop seasons, 'Fuentepina' showed good shelf life. Its calyx freshness was higher than that of the other cultivars in 2008 and similar to 'Camarosa' but higher than 'Aguedilla' and 'Sabrosa' in 2009. 'Fuentepina' also showed high resistance to bruising during the two trials.

The resistance of 'Fuentepina' to Phythophthora cactorum (Lebert \& Cohn) and Verticillium dahliae Kleb. was similar to that observed for 'Camarosa'; however, susceptibility to Podosphaera aphanis (Wallr.) was greater (de Cal and de los Santos, personal communication).

\section{Availability}

The Andalusian government (IFAPA Junta de Andalucia), IVIA, INIA, FNM, NTF, and FV have jointly applied for an inscription in the Register of Commercial Strawberry Varieties (Spanish Plant Variety Office, application number 20070358) and for a Community Plant Variety Right (CPVO, application number 20090750) in the European Union territory. Parties interested in propagating this cultivar should contact Fresas Nuevos Materiales S.A., Plz. Puerto Moral 2, portal 1, 6 A, 21007 Huelva, Spain. E-mail: arefoyo@fresasnm.com.

\section{Literature Cited}

Dominguez, F., D. Borrero, J.J. Medina-Minguez, J. Regidor, M.T. Ariza, F. Delgado, M.D. Delgado, F. Fernández, F. Flores, J. Gálvez, F.J. Garrido, J.M. López-Aranda, J. López Medina, L. Miranda, C.J. Pérez, M.D. Sánchez, C. Soria, and C. Vélez. 2004. Ensayo de variedades de fresa. Campaña 2004. p. 1-42. In: Consejería de Agricultura y Pesca, Junta de Andalucía (ed.). RAEA. Servicio de Publicaciones y Divulgación, Sevilla, Spain.

Gil-Ariza, D.J., I. Amaya, M.A. Botella, J. MuñozBlanco, J.L. Caballero, J.M. López-Aranda, V. 
Valpuesta, and J.F. Sánchez-Sevilla. 2006. EST-derived polymorphic microsatellites from cultivated strawberry (Fragaria Xananassa) are useful for diversity studies and varietal identification among Fragaria species. Mol. Ecol. Notes 6:1195-1197.

López-Aranda, J.M., C. Soria, J.F. SánchezSevilla, J. Gálvez, J.J. Medina, A. Arjona, J.I Marsal, and R. Bartual. 2004. 'Marina' strawberry. HortScience 39:1776-1777.

López-Aranda, J.M., C. Soria, J.F. SánchezSevilla, J. Gálvez, J.J. Medina, A. Arjona, J.I.
Marsal, and R. Bartual. 2005a. 'Medina' strawberry. HortScience 40:482-483.

López-Aranda, J.M., C. Soria, L. Miranda, J.F. Sánchez-Sevilla, J. Gálvez, R. Villalba, F. Romero, B. De Los Santos, J.J. Medina, J. Palacios, E. Bardón, A. Arjona, A. Refoyo, A. Martínez-Treceño, A. De Cal, P. Melgarejo, and R. Bartual. 2005b. 'Aguedilla' strawberry. HortScience 40:2197-2199.

Medina-Mínguez, J.J. 2002. Soil solarization and biofumigation in strawberry in Spain. Proc. International Conference on Alternatives to
Methyl Bromide. The remaining challenges. Seville, Spain. p. 123-125.

Soria, C., J.F. Sa'nchez-Sevilla, M.T. Ariza, J. Ga'lvez, J.M. López-Aranda, J.J. Medina, L. Miranda, A. Arjona, and R. Bartual. 2008. 'Amiga' strawberry. HortScience 43:943-944.

UPOV. International union for the protection of new varieties of plants. 1995. Guidelines for the conduct of test for distinctness, uniformity and stability - Strawberry (Fragaria L.). UPOV publication TG/22/9, Geneva, Switzerland. $<$ www.upov.int $>$. 